\title{
Environmental variability and human activity over the past 140 years documented by sediments of Ebinur Lake in arid central Asia
}

\author{
Wen LIU, ${ }^{1}$ Long MA,,$^{1,2}$ Jinglu WU, ${ }^{3 *}$ Jilili ABUDUWAILI ${ }^{1,2}$ \\ ${ }^{1}$ State Key Laboratory of Desert and Oasis Ecology, Xinjiang Institute of Ecology and Geography, Chinese Academy of Sciences, \\ Urumqi 830011; ${ }^{2}$ CAS Research Center for Ecology and Environment of Central Asia, Urumqi; ${ }^{3}$ State Key Laboratory of Lake \\ Science and Environment, Nanjing Institute of Geography and Limnology, Chinese Academy of Sciences, Nanjing 210008, China \\ *Corresponding authors: malong@ms.xjb.ac.cn; W.jinglu@niglas.ac.cn
}

\begin{abstract}
A short (50-cm-long) sediment core from Ebinur Lake in arid central Asia has been analyzed for various environmental proxies, including organic matter content, $\delta^{13} \mathrm{C}$ in organic matter, magnetic susceptibility, heavy metal contents, and stable isotopic compositions of bulk carbonate $\left(\delta^{18} \mathrm{O}\right.$ and $\left.\delta^{13} \mathrm{C}\right)$. The results reveal that the evolutionary stages inferred from environmental indicators have an asynchronous nature. If the asynchrony of periodic changes in multi-environmental proxies is ignored, important information may be lost, especially regarding anthropogenic influences. On the basis of magnetic susceptibility and heavy metal contents, human activities appear to have resulted in increases in surface erosion and measurable heavy-metal accumulation from the mid1960 s, whereas the organic matter contents, which display an obvious shift in the late 1930s, correlate with regional climate. However, the changes in the stable isotopes of bulk carbonate are mainly controlled by the isotopic composition of the host water which is generally consistent with the lake level. From the late 1870 s to the 1960 s, the lake was in a natural evolutionary state. From the 1960 s to the mid-2000s, the runoff feeding Ebinur Lake dropped rapidly, in association with a sharp increase in agricultural development. Finally, beginning in the early twenty-first century, the climate became wetter than during the earlier two stages, and as agricultural water demand decreased, surface runoff once again increased. It is noted that, although the different proxies respond differently to climate changes and human activities, any analysis of environmental evolution should consider them each individually, in order to fully understand the complex interactions between climate and human influence.
\end{abstract}

Key words: Environmental variability; anthropogenic influence; climate change; lacustrine sediment; Ebinur Lake; central Asia.

Received: October 2016. Accepted: April 2017.

\section{INTRODUCTION}

Various sedimentary processes can incorporate both internal and external materials into lake sediments, and this matter may contain important environmental information about lakes and their watersheds (Meyers, 2003; Birks et al., 2004; Thevenon et al., 2013; Qiang et al., 2014). As a result, the lacustrine sediments of central Asia have been the focus of a number of paleo-environmental studies (Austin et al., 2007; Chen et al., 2008; Chiba et al., 2016). For instance, data spanning the last millennium show that humidity has increased during the recent period of global warming in arid central Asia (Chen et al., 2010). Additionally, an 8500-year peat record from Chaiwopu Lake in this region also contains a record of steadily increasing summer rainfall (Hong et al., 2014). However, increasing aridity over the past century across the entire central Asian region has been inferred, on the basis of observations and global climate models (Donat et al., 2016). Thus, the prevailing environmental conditions in this area over the last 100 years remain poorly understood and as yet unresolved. To address this issue, the closed inland Lake Ebinur, which is influenced by westerlies and is sensitive to environmental and climate changes (Wu et al., 2009; Ma et al., 2011, 2016), represents an ideal area for investigation; study of this lake will add to the existing environmental data, and help to resolve climate trends in arid central Asia.

In paleo-environmental studies spanning long time scales, changes in multiple proxies are used to represent variations in climatic conditions and the resultant environmental changes. However, over the last century, human activities have produced environmental variations having an unprecedented degree and scope. In developed areas, these anthropogenic changes have become an important factor affecting the evolution of lakes such as Lake Taihu (Peng et al., 2016), Lake Fuxian (Liu et al., 2009), and Poyang Lake (Ye et al., 2013). In some cases, they are even the dominant controlling factor. Even in the Eastern Tibetan Plateau, the contamination history of lake sediments has revealed that heavy metal pollution has occurred as a result of anthropogenic emissions since the 
mid-1990s (Bing et al., 2016). In contrast, in developing areas such as arid central Asia, researchers have focused primarily on the effects of climate change on basin environments (Aizen et al., 1997; Yu et al., 2003; Lioubimtseva and Henebry, 2009), and the degree to which human activities have influenced landscape processes is not yet clear. It is expected that multiple proxies from lake sediments will be extremely useful in assessing the role of human activities on environmental processes.

In this study, a sediment core covering the recent part of the historical times period was extracted from Ebinur Lake for environmental proxy analysis. The records from this core were used to explore i) the environmental conditions over the last 150 years; ii) the degree of influence that human activities have had on the environment in central Asia; and iii) the factors that are potentially responsible for these relatively recent environmental changes.

\section{Study site}

Ebinur Lake $\left(44^{\circ} 30^{\prime}-44^{\circ} 42^{\prime} \mathrm{N}, 81^{\circ} 05^{\prime}-81^{\circ} 15^{\prime} \mathrm{E}\right)$ is a closed lake in central Asia that lies near the border between China and Kazakhstan (Fig. 1). The water level is $194 \mathrm{~m}$ above sea level, and the lake covers an area of 527 $\mathrm{km}^{2}$ (Ma et al., 2014). Moreover, the catchment area is $50,621 \mathrm{~km}^{2}$, and the recharge coefficient is 97.0 (Wang and Dou, 1998). Additionally, although the lake watershed was once fed by 12 tributary rivers (Yao et al., 2014), the Boertala, Jing, and Kuitun Rivers are the only three rivers that directly feed surface water into the lake today.

Meteorological stations at a mountain site (Wenquan station; operating 1959-2013), and at a location on the plain (Jinghe station; operating 1953-2013) (locations shown in Fig. 1) provide climate data for the variation analysis performed in this study (Fig. 2). The curves of mean annual temperature and mean wintertime temperature (Dec-Feb) show an increasing trend over the last half century. In addition, upward trends are seen in the total annual precipitation and total wintertime precipitation (Fig. 2) in both the mountainous and plain regions of the Ebinur basin.

\section{METHODS}

Using a gravity corer (Uwitec, Mondsee, Austria) with a $6 \mathrm{~cm}$-diameter plastic tube, a short, $50 \mathrm{~cm}$-long sediment core $(\mathrm{AB} 01)$ was extracted from Ebinur Lake, which has a water depth of $2.4 \mathrm{~m}$ at the sampling site $\left(82.9603^{\circ} \mathrm{E}\right.$, $44.9113^{\circ} \mathrm{N}$ ) (Fig. 1). After collection, the core was subsampled at $1-\mathrm{cm}$ intervals in the field, and samples were packed in airtight zip-lock plastic bags and refrigerated. After freeze-drying, these samples were used for dating and multi-proxy analysis. All analyses were carried out at the State Key Laboratory of Lake Science and Environ- ment in Nanjing Institute of Geography and Limnology, Chinese Academy of Sciences.

An age-depth model was established on the basis of the activities of ${ }^{210} \mathrm{~Pb},{ }^{226} \mathrm{Ra}$ and ${ }^{137} \mathrm{Cs}$, which was performed using an EG\&G Ortec Gamma Spectrometer with a low-level germanium detector (EG\&G ORTEC, HPGe GWL). Bulk sediments $(0.125 \mathrm{~g}, 200 \mathrm{mesh})$ were digested in a Berghof MWS-3 microwave digester by $0.5 \mathrm{ml} \mathrm{HCl}$, $6 \mathrm{~mL} \mathrm{HNO}_{3}$ and $3 \mathrm{~mL} \mathrm{HF}$ for $15 \mathrm{~min}$, then moved to teflon beakers after cooling, added $0.5 \mathrm{~mL} \mathrm{HClO}_{4}$, evaporated to dryness at $200^{\circ} \mathrm{C}$. After that, $2.5 \mathrm{~mL} 1 \mathrm{~mol} / \mathrm{L}$ $\mathrm{HNO}_{3}, 0.25 \mathrm{~mL} \mathrm{H}_{2} \mathrm{O}_{2}$ and $5 \mathrm{~mL}$ deionized water were added for dissolving residue by heating, then totally moved to constant volume for analysis, and the geochemical elements were analyzed by a Leeman Labs Profile Inductively Coupled Plasma Spectrometer (ICP-AES) with a relative error of less than $5 \%$. Quality control was assured by the analysis of duplicate samples, blanks and GSD-9 and GSD-11 standard reference material (Chinese geological reference materials).

The content of total organic carbon (TOC) was determined by oxidation with potassium dichromate (Walkley and Black, 1934). For analysis of total nitrogen (TN), the samples were digested by alkaline potassium persulfate at high temperature and then measured using an ultraviolet spectrophotometer at $210 \mathrm{~nm}$. The samples dried for organic carbon isotopic analysis were leached with $\mathrm{HCl}$ $(1 \mathrm{~mol} / \mathrm{L})$, and then the sample was washed with deionized water to neutral. The analysis of organic matter $\delta^{13} \mathrm{C}$ was carried out with an isotope ratio mass spectrometer (MAT251), and isotope ratios are reported in per mil (\%o) relative to the VPDB standard, the analytical precision was less than $0.05 \%$. The carbonate contents of the lake sediments were determined by the volumetric calcimeter method (Loeppert and Suarez, 1996), which has an error of less than 5\%. After the removal of organic matter, the $\delta^{13} \mathrm{C}$ and $\delta^{18} \mathrm{O}$ of the bulk carbonate were measured using an isotope ratio mass spectrometer (MAT-253), and the results are reported in per mil $(\%)$ relative to the VPDB. The analytic error for $\delta^{18} \mathrm{O}$ was less than $0.08 \%$, and this quantity was less than $0.03 \%$ for $\delta^{13} \mathrm{C}$. Finally, magnetic susceptibility (MS) was measured at low frequency $(460 \mathrm{~Hz})$ using the MS2 Magnetic Susceptibility System, which is produced by Bartington Instruments, Oxford, England.

Element enrichment factors (EFs) were first calculated to reveal the origins of the elements (Reimann and De Caritat, 2005). The calculation of EFs can be generalized as: $\mathrm{EF}=\left(\left(\mathrm{M}_{\text {sample }} / \mathrm{R}_{\text {sample }}\right) /\left(\mathrm{M}_{\text {background }} / \mathrm{B}_{\text {ackground }}\right)\right.$ (Loska et al., 1997), where (M/R) is the ratio of heavy metal concentration $(M)$ with respect to a reference element $(R)$ in the sediment in mass or mass units, and the subscripts "sample" or "background" indicate the medium to which the concentration refers. As a lithogenic element (Price et al., 1999), aluminum is often chosen as the reference el- 
ement $(\mathrm{R})$ to normalize concentrations and to distinguish anthropogenic influences (Bourennane et al., 2010; Gu et al., 2012; Rauch et al., 2004; Muller et al., 2006). The geochemical background values were deduced from the PIRLA procedure (Binford, 1990).
The Fisher optimal segmentation model with the software DPS 7.05 (Tang and Zhang, 2013) and stratigraphically constrained clustering with the software PAST, version 3.01 (Hammer, 2013) were used to achieve hierarchical clustering of environmental proxies, which was
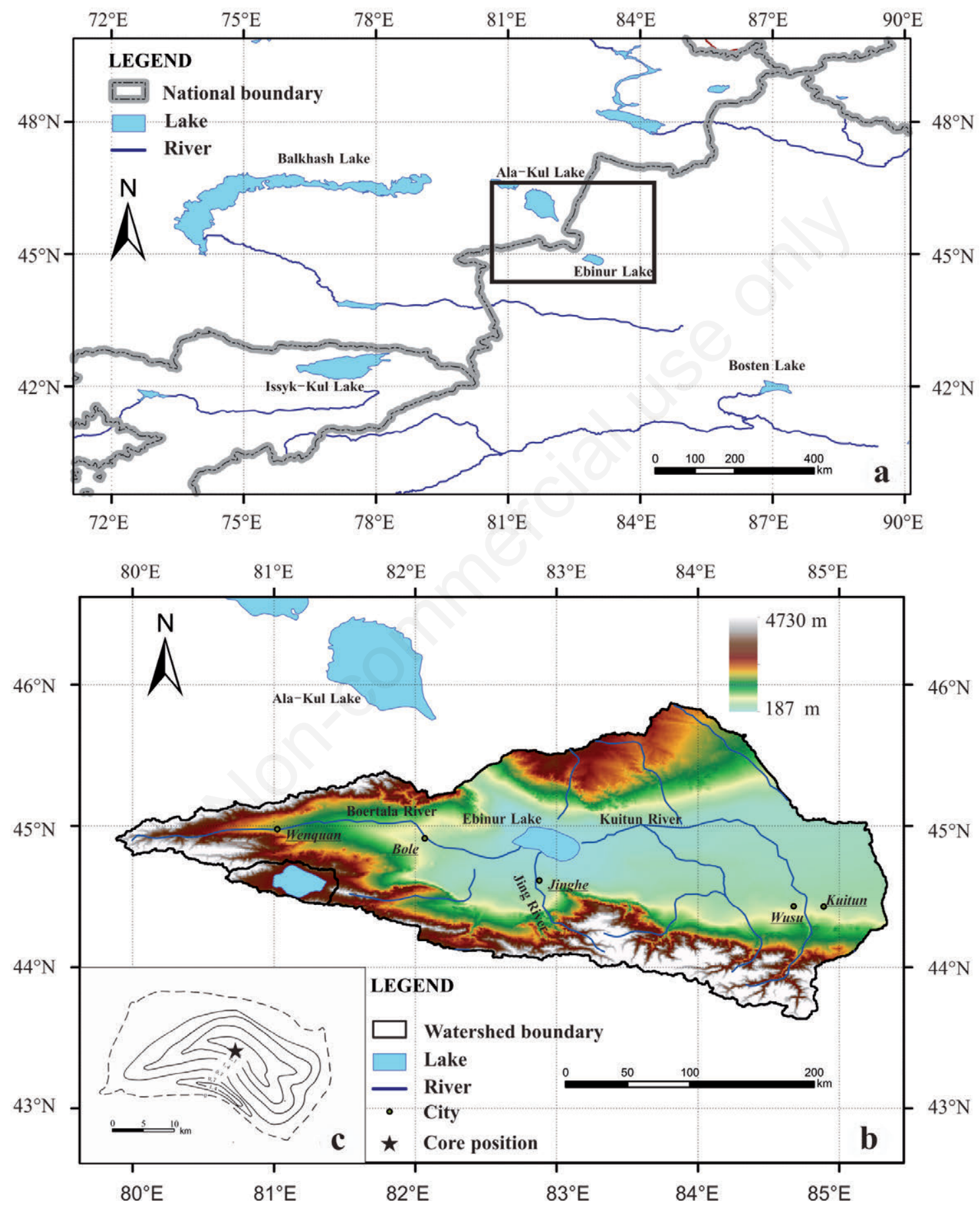

Fig. 1. Geographical position of Ebinur Lake in central Asia and location of the sample core. a) Location of Ebinur Lake within the surrounding region. b) Map of the Ebinur Lake basin showing relief, major rivers, and the positions of cities and meteorological stations. c) Map of the bathymetry of Ebinur Lake and the core location. 
used to reveal the evolutionary phases. The Fisher method is an algorithm based on minimizing the weighted sum of within-group sums of squared distances to the group centroids (Legendre, 1987). Stratigraphically constrained clustering method will allow only adjacent layers to be joined during the agglomerative clustering procedure. The result was given as a dendrogram with European distance as a representation for the dissimilarity among the groups of layers.

\section{RESULTS AND DISCUSSIONS}

\section{Chronology}

The vertical distributions of the activities of ${ }^{210} \mathrm{~Pb}$ and ${ }^{137} \mathrm{Cs}$ are shown in Fig. 3. The total ${ }^{210} \mathrm{~Pb}$ activity in the core declined to a level of approximately $58 \mathrm{~Bq} / \mathrm{kg}$ at $49 \mathrm{~cm}$
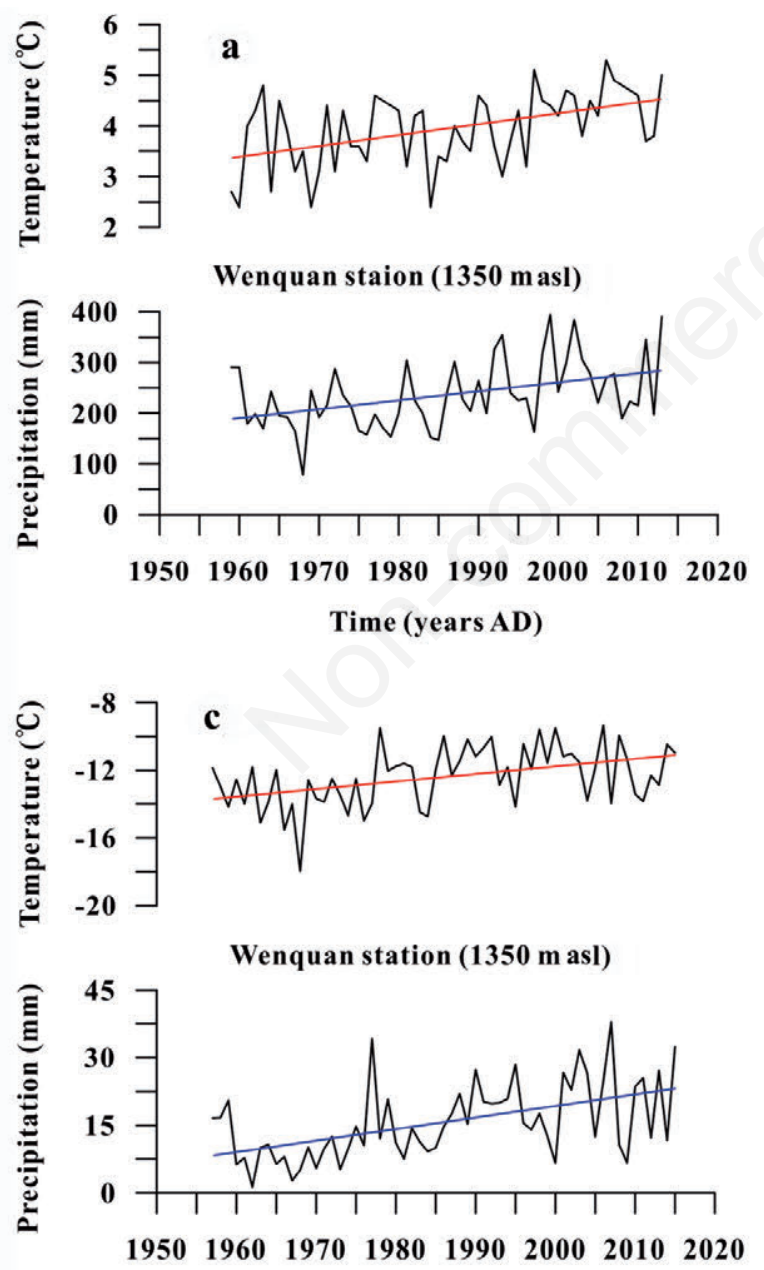

Time (years AD)
(Fig. 3). On the basis of unsupported ${ }^{210} \mathrm{~Pb}$ activities $\left({ }^{210} \mathrm{~Pb}\right.$ ex $\left({ }^{210} \mathrm{~Pb}_{\mathrm{ex}}=\right.$ total $\left.{ }^{210} \mathrm{~Pb}-{ }^{226} \mathrm{Ra}\right)$, a sedimentary chronology was constructed for Ebinur Lake following a constant rate of supply model (CRS) model (Appleby, 2002).

Activity of ${ }^{137} \mathrm{Cs}$ was first detected at a depth of $25 \mathrm{~cm}$, representing the year $1954 \mathrm{AD}$ (Klaminder et al., 2012). The peak ${ }^{137} \mathrm{Cs}$ values at $20 \mathrm{~cm}$ represent the year $1963 \mathrm{AD}$, during which year the maximum rates of deposition occurred in the Northern Hemisphere (Pennington et al., 1973). The surface layer corresponds to sampling time in 2011 AD. Thus, the depth interval $25-20 \mathrm{~cm}$ corresponds to AD 1954-1963, whereas $20-0 \mathrm{~cm}$ corresponds to AD 1963-2011. The temporal resolutions of the subsamples for the two periods were $1.8 \mathrm{a} \mathrm{cm}^{-1}$ and $2.4 \mathrm{a} \mathrm{cm}^{-1}$, respectively. This result agrees with the ${ }^{210} \mathrm{~Pb}$ CRS model (Fig. 3). The age model was established using these values, and appeared in Ma et al., 2016.
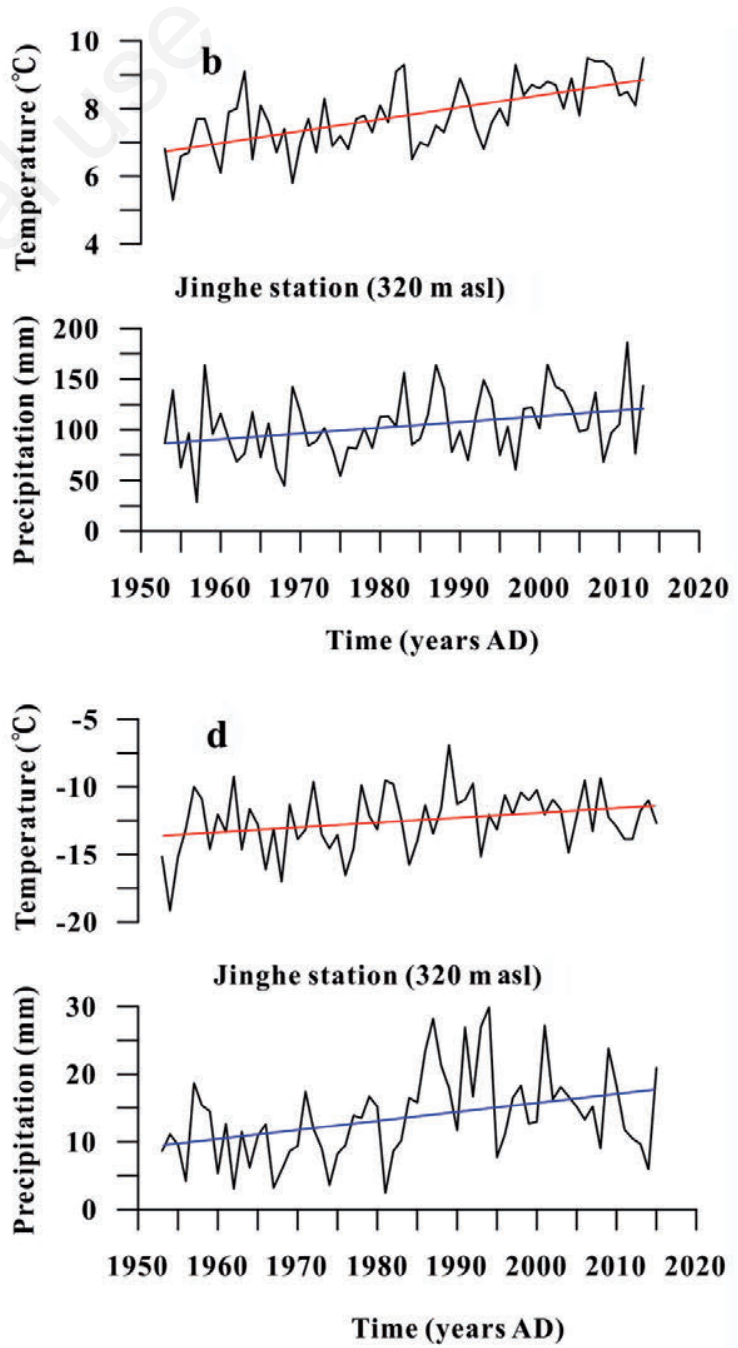

Fig. 2. Curves showing temperature and precipitation in the study area, with best-fit linear trends. a) Mean annual temperature and precipitation at Wenquan station. b) Mean annual temperature and precipitation at Jinghe station. c) Mean wintertime temperature and total wintertime precipitation at Wenquan station. d) Mean wintertime temperature and total wintertime precipitation at Jinghe station. 


\section{Organic geochemical markers} and their environmental implications

The variations in TOC, $\mathrm{TN}, \mathrm{C} / \mathrm{N}$, and $\delta^{13} \mathrm{C}_{\text {org }}$ with time are presented in Fig. 4. The TOC values fell within a range of $0.67 \%-1.10 \%$, with an average value of $0.93 \%$, and a general increase in these values from the bottom to the top of the core was noted. The TOC content in the lower levels showed significant fluctuations. The contents of total organic nitrogen varied over a range of 318-1150 $\mathrm{mg} / \mathrm{kg}$ and followed a trend that was approximately similar to that of TOC. C/N values were in the range of 8.5-27.9 with an average of 14.9. In the lower part of sediment core $\mathrm{AB} 01, \mathrm{C} / \mathrm{N}$ values fluctuated significantly, but remained stable until the 1940 s, following a gradual increasing trend towards the top of the core. Values of $\delta^{13} \mathrm{C}_{\text {org }}$ ranged from $-22.6 \%$ to $-20.96 \%$, and the average value was $-21.69 \%$.

Representative elemental and carbon isotopic compositions of organic matter from lacustrine algae, C3 land plants, and C4 land plants are shown in Fig. 5 (Meyers and Teranes, 2002). The proportional inputs of terrestrial and aquatic plant matter are therefore important in determining the carbon isotope value of bulk organic matter
(Fig. 5). $\mathrm{C} / \mathrm{N}$ ratios are also frequently used to estimate the source of organic matter; aquatic plants generally have values less than 10 , while land plants commonly have values between 20 and 30 (Meyers and Lallier-Vergès, 1999). The $\mathrm{C} / \mathrm{N}$ values of the Ebinur Lake sediment core were mostly between 10 to 20 , and the ratios in the lower part of the sediment core were typically greater than 20 , which indicate that the organic matter originated mainly from exogenous terrestrial vegetation.

The results of the Fisher optimal segmentation model and stratigraphically constrained clustering methods suggested there are two distinct phases with the boundary of 1940s, and the results can be analyzed in terms of three aspects. First, the organic matter contents show an obvious shift in the 1940s, from which an environmental event may be inferred (Fig. 4). In general, the TOC concentration is a fundamental parameter for describing the abundance of organic matter in sediments, and values of this parameter can be used to indicate organic productivity (Meyers and Lallier-Vergès, 1999). If considerable human activity had been present in the lake catchment, the sharp increase in TN since the 1940s could be attributed to agricultural development. However, in 1949, the population in the whole of Xinjiang province was only 4.3 million
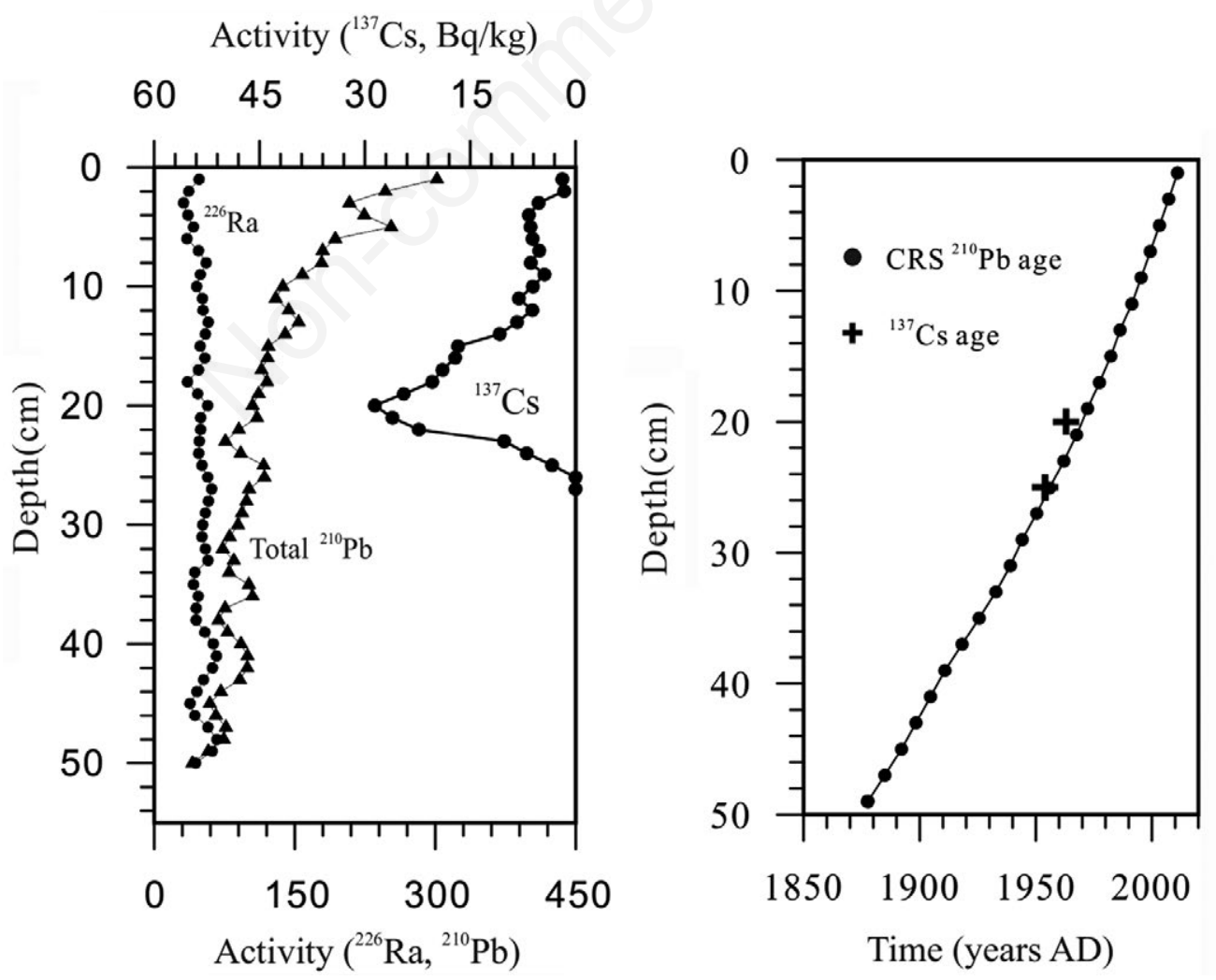

Fig. 3. Age model for the Ebinur Lake core $\mathrm{AB} 01$. a) The activity of ${ }^{137} \mathrm{Cs}$ (note inverted scale) and unsupported ${ }^{210} \mathrm{~Pb}$ activity $\left({ }^{210} \mathrm{~Pb}\right.$ ex versus depth in the sediment core $\mathrm{AB} 01 . \mathrm{b})$ Age-depth relation based on ${ }^{210} \mathrm{~Pb}$ and ${ }^{137} \mathrm{Cs}$ dating. 
(Sabit and Yusup, 2007). Large-scale development activities started after the liberation. The intensity of human activity in 1940s in the lake catchment was not enough to cause the sharp increase in TN and TOC.

Second, in the upper part of the core, which covers the period from the 1940s to the present day, the mean values of TOC and TN were higher than in the lower parts. Temperature is a primary factor affecting the rate of plant development (Hatfield and Prueger, 2015). Air temperatures have increased globally over the last century, and central Asia has also experienced warming (Lioubimtseva et al., 2005; Stocker et al., 2014). An IPCC report showed that increases in grain crop output at mid- and high-latitudes resulted in accompanying increases in carbon dioxide, an expansion of the growing season, and higher temperatures for plant growth (Adger et al., 2007). In addition, meltwater from snow can have a direct impact on primary productivity in arid lands. Measurements taken at local meteorological stations show an increase in winter precipitation, which is supported by previous studies that have attributed the observed trend toward increasing amounts of annual precipitation in mid-latitude Asia to changes in winter precipitation (Huang et al., 2013). It is inferred that the climatic conditions since the 1940s, promoted watershed primary productivity more effectively. In this and adjacent regions, such as Lake Sayram (Liu et al., 2014) and Chaiwopu Lake (Ma et al., 2013), the climate was also suitable for plant growth, as suggested by the lacustrine sediment records.

Finally, it is obvious that the TOC and TN have remained stable since the 1940s. From the above discussion, the suitable conditions for plant growth, in addition to the human-driven occurrence of overgrazing in the lake catchment, should lead to enhanced increases in the values of TOC and TN. Following the trends in social and economic development, the sharply increasing water demands caused a dramatic decrease in surface runoff and counteracted the effects of the suitable climatic conditions. Moreover, no analogous changes are observed for the carbon isotopic composition of organic matter and the $\mathrm{C} / \mathrm{N}$ ratios since the 1940s (Fig. 4). If the watershed were in its natural state, these observations would suggest that

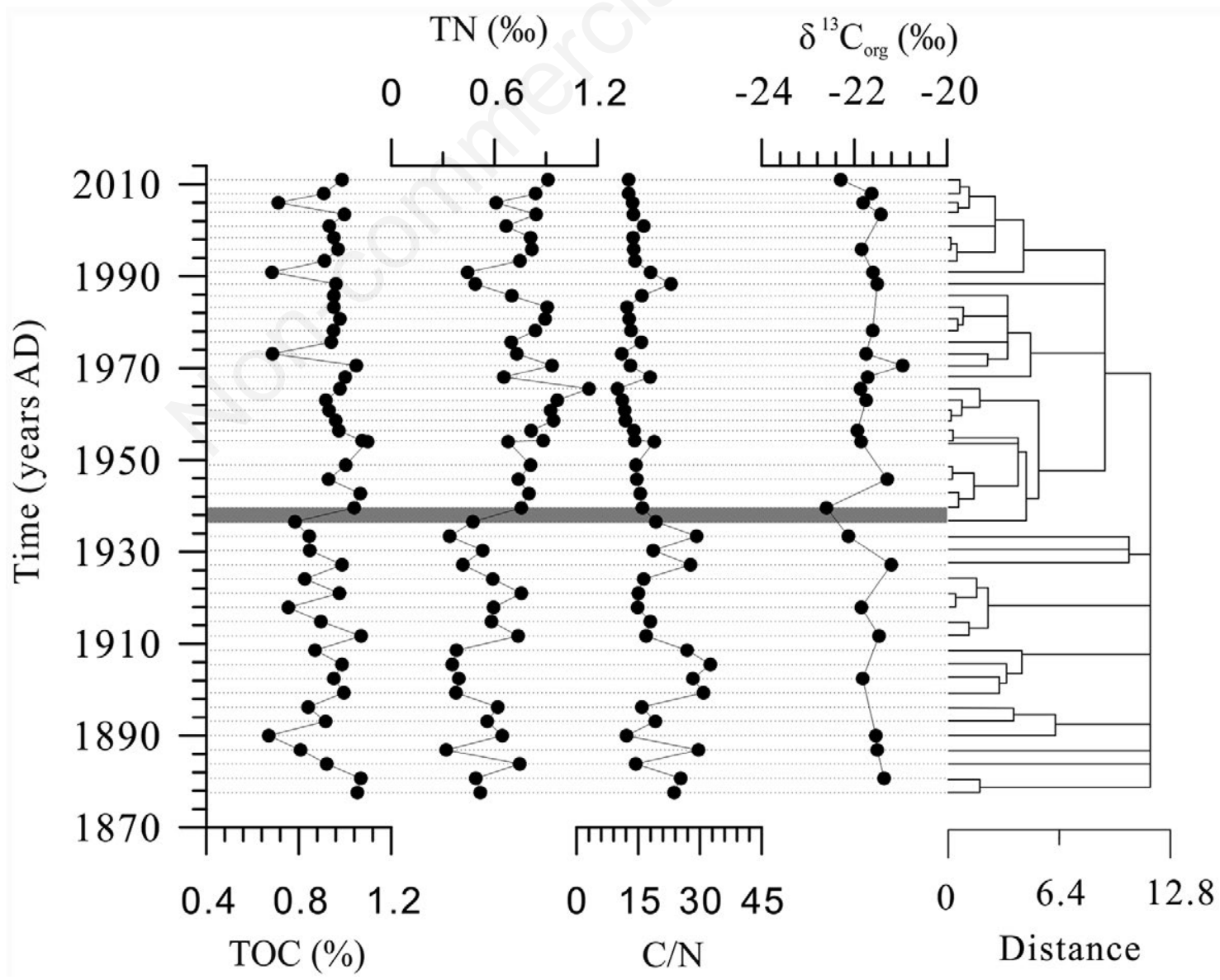

Fig. 4. Variations in organic matter indices (TOC, TN, C/N, and $\delta^{13} \mathrm{C}_{\mathrm{org}}$ ) in Ebinur Lake sediment core AB01. 
the biome has been similar over the past six decades. However, given the impacts of human activities, which change surface runoff, water erosion, and vegetation composition, these activities are likely to cause this special phenomenon.

\section{Heavy-metal enrichment and its potential ecological risks}

The heavy metal contents in the lake sediments are shown in Fig. 6. Geochemical background values are indicated with a dotted line. As shown in Fig. 6, the heavy metal concentrations showed similar distribution patterns, which showed apparent increases from the 1950s. These variations were consistent with the changes in magnetic susceptibility (MS).

The EF values and stage characteristics by stratigraphically constrained clustering and Fisher optimal segmentation model are plotted in Fig. 6. Increasingly severe, human-induced heavy-metal accumulations first appeared in the 1960s, which is consistent with the stepped change and state division observed in the magnetic susceptibility data obtained from the Ebinur Lake sediments. Magnetic susceptibility data are typically used to infer relative changes in surface erosion of fine materials from well-developed soil profiles (Dearing et al., 2008); in this study, it is associated with human activity in the basin, as seen from its covariation with the total sown area of farm crops in Jinghe County over the last half century (Fig. 6). From the early 2000s, the EFs of all heavy metals showed a slight decline. This is likely related to the fact that, in June 2000, the Xinjiang Autonomous Region People's Government approved the establishment of a wetland nature reserve in the region, which provided substantial protection for the wet lands in the lake catchment. Wetlands are able to remove heavy metals from the environment by absorbing and binding them into the sediment, which then decreases their concentrations in the runoff that enters the lake (Zhang et al., 2012).

The EFs of heavy metals in Ebinur Lake show con-

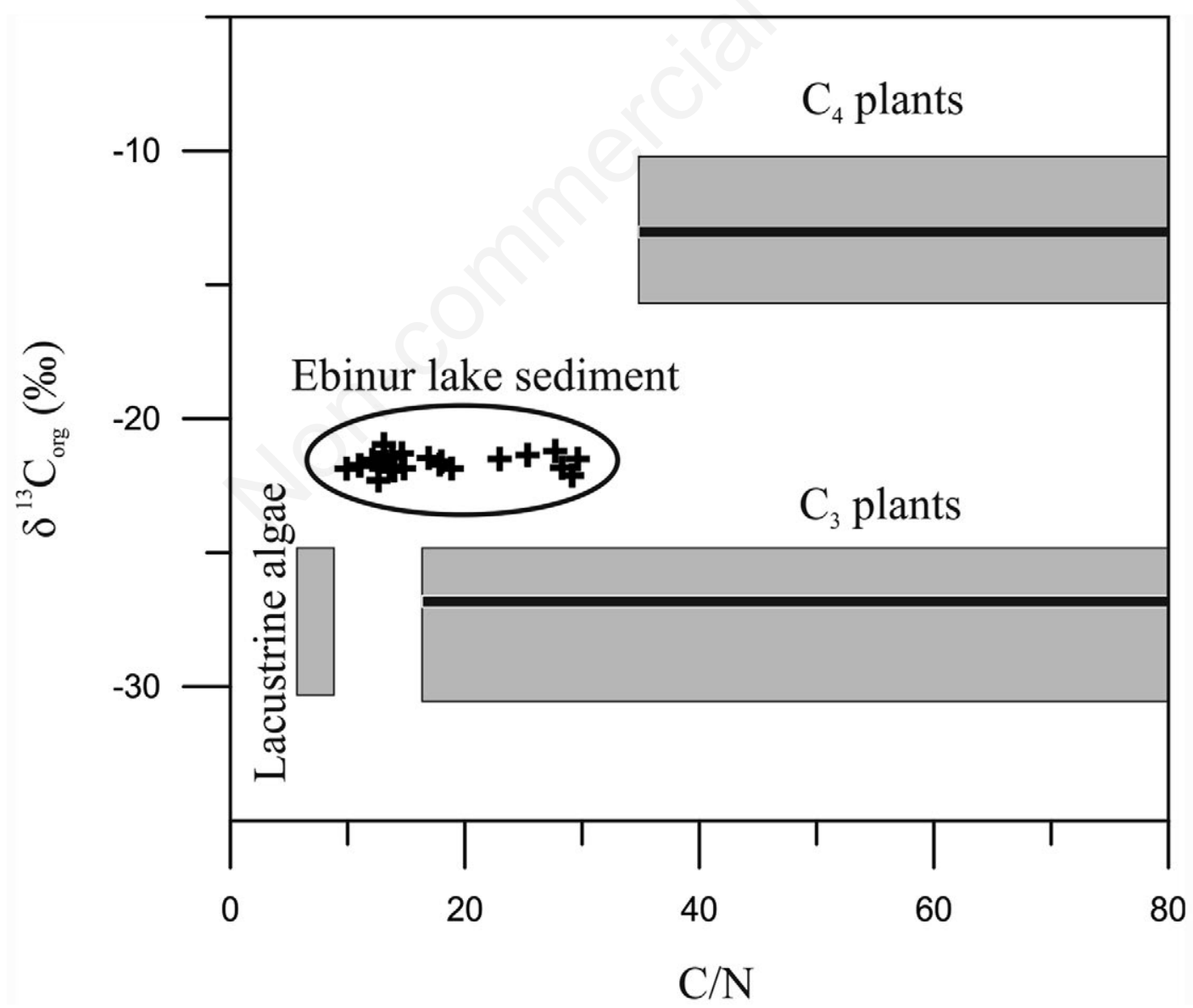

Fig. 5. Organic carbon isotopic values versus $\mathrm{C} / \mathrm{N}$ of organic matter, compared with the model of sedimentary organic matter (Meyers and Teranes, 2002). The solid line represents the stable carbon isotope compositions of desert C3 and C4 plants of the Junggar Basin (Sun et al., 2007). 
spicuous variations (Fig. 6), which indicate that the changing intensity of human activity has influenced the local basin environment over the last one and a half centuries. However, a potential ecological risk assessment for the toxicity of these heavy metals (Hakanson, 1980) reveals that the risk is very slight. As suggested by the enrichment factors, though the risk seems not to have been severe over the past half century, anthropogenic influences on heavy-metal pollution are emerging, which require the attention of the public and the government.

On the basis of the EFs and MS proxies described above, it is clear that anthropogenic activities have resulted in increased catchment erosion and measurable heavy-metal accumulation since the mid-1950s in this basin. With these results, combined with previous work on the nearby Lake Sayram (Liu et al., 2014), Chaiwopu Lake (Ma et al., 2013), and Bosten Lake (Zhang et al., 2009), the impacts of human activity in arid central Asia since the 1960s are beginning to emerge. Human activities have resulted in an increase in watershed erosion, and they affect the environment through the emission of pollutants. However, a sharp increase in industrial and agricultural water demand has also reduced the water supply for ecological systems, leading to dramatic changes in the runoff passing into the tail-end lakes, which significantly influences the ecological environment of the lakes. Therefore, in general, it can be seen that the effects of human activities in Central Asia have been superimposed on global climate changes and have affected the regional environment for more than 50 years.

\section{Stable isotope record from bulk carbonates and its inferred environmental changes}

Variations in carbonate content, $\delta^{13} \mathrm{C}_{\text {carb }}$ and $\delta^{18} \mathrm{O}_{\text {carb }}$ are shown in Fig. 7. Carbonate contents were approximately $15.6 \%-31.2 \%$ with an average of $24 \%$, and these contents mainly decreased upwards along sediment core AB01. $\delta^{13} \mathrm{C}_{\text {carb }}$ varied between $-0.94 \%$ and $3.17 \%$, and the values of $\delta^{18} \mathrm{O}_{\text {carb }}$ ranged from $-5.37 \%$ to $-3.39 \%$. In this study of Ebinur Lake, the correlation coefficient between these two quantities was $0.46(\mathrm{P}=0.027<0.05)$, which is expected, since isotopic correlations are often recognized between $\delta^{18} \mathrm{O}$ and $\delta^{13} \mathrm{C}$ in closed-basin lakes (Fritz et al., 1975; Talbot, 1990; Lewis and Anderson, 1992; Xu et al., 2006; Liu et al., 2014).

Carbon isotope values are mainly controlled by the isotopic composition of dissolved inorganic carbon $\left(\delta^{13} C_{\text {DIC }}\right)$ in the water (Liu et al., 2014). Large-scale evaporation of lake water will result in an enrichment of $\delta^{13} \mathrm{C}_{\mathrm{DIC}}$ in the water, as well as in the resulting carbonate (Xu et al., 2006). The oxygen isotopes in carbonate sediments are controlled mainly by the isotopic composition of the host water, as well as water temperature, since the carbonates are precipitated at isotopic equilibrium with the ambient water.

Under the natural background, the ratio of precipitation to evaporation $(\mathrm{P} / \mathrm{E})$ is the primary control on lake levels, as well as the heavy-isotope enrichment of the lake water (Ma et al., 2011). A decrease in $\delta^{18} \mathrm{O}$ values largely reflects an increase in the $\mathrm{P} / \mathrm{E}$ ratio within the basin, likely under

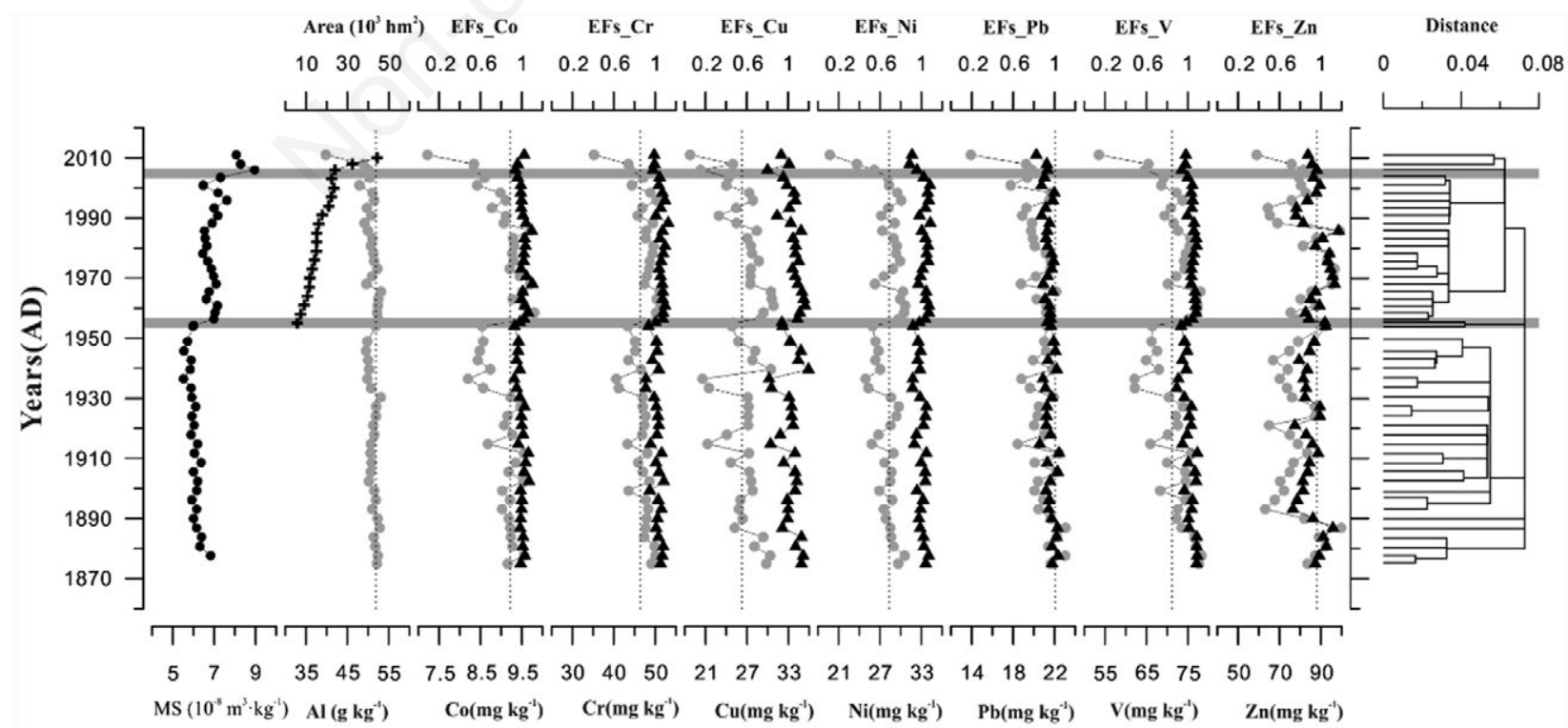

Fig. 6. Profiles of elemental concentrations (solid line with gray dots) and the results of a constrained cluster analysis for the enrichment factors (EFs) (solid lines with black triangles) in the Ebinur Lake sediment core, compared to the magnetic susceptibility (MS, solid line with black dots) and the total area sown with food crops in Jinghe County (solid lines with crosses). 
wet climatic conditions with high precipitation and/or low evaporation. However, local meteorological data collected since the 1950s reveals that regional precipitation has been steadily increasing in both the mountainous and plain regions of the Ebinur basin. Thus, at face value, there appear to be an inconsistency between the isotopic composition and regional precipitation since the 1960s.

With the considerable influences from human activity, especially since the 1960s, agriculture across the whole country has developed rapidly. New villages and towns have been established, and certain industries have developed in the plains of this area. Thus, since the 1960s, increased agricultural water demands in the Ebinur watershed have resulted in a dramatic decrease in runoff, which has influenced the lake level and the isotopic composition of the host water.

From the early twenty-first century, the climate was wetter than during the earlier two stages, and as agricultural water demand decreased, surface runoff once again increased. It is also obvious that the lake area change from 2003 to 2010 is inconsistent with the unidirectional decline of the sediment proxies, such as the oxygen and carbon isotopic compositions of carbonates. Because of the increase in surface runoff since the early 2000s (Ma et al., 2014), the contribution of exogenous carbonate from the catchment may result in a negative bias.

Through the above mentioned analysis, there are fluctuations in environmental proxies, but not very striking, which suggested that there were no sudden changes in re- gional environments over the past 140 years. The results also reveal that the evolutionary stages inferred from environmental indicators have an asynchronous nature. For example, measurable heavy-metal accumulation occurred from the mid 1960s, whereas the organic matter contents displayed an obvious shift in the late 1930s. If the asynchrony of periodic changes in multi-environmental proxies is ignored, important information may be lost, especially regarding anthropogenic influences.

Lake sediments record the climate change and human activities in the Ebinur Lake watershed. For quantitatively distinguishing the influences of human activity and climate change, there is need to build a mathematical model with effective environment variables (Ma et al., 2014). In consideration of the lacks of comprehensive and long-time series data about human activities and climate change, the impacts of environmental forcing have only been evaluated through a generally descriptive way in this study.

\section{CONCLUSIONS}

Sediment records spanning 150 years from Ebinur Lake were used to identify environmental change influenced by anthropogenic and climatic factors in this typical central Asian basin.

The organic matter contents can be used to indicate organic productivity, which correlates with regional humid-

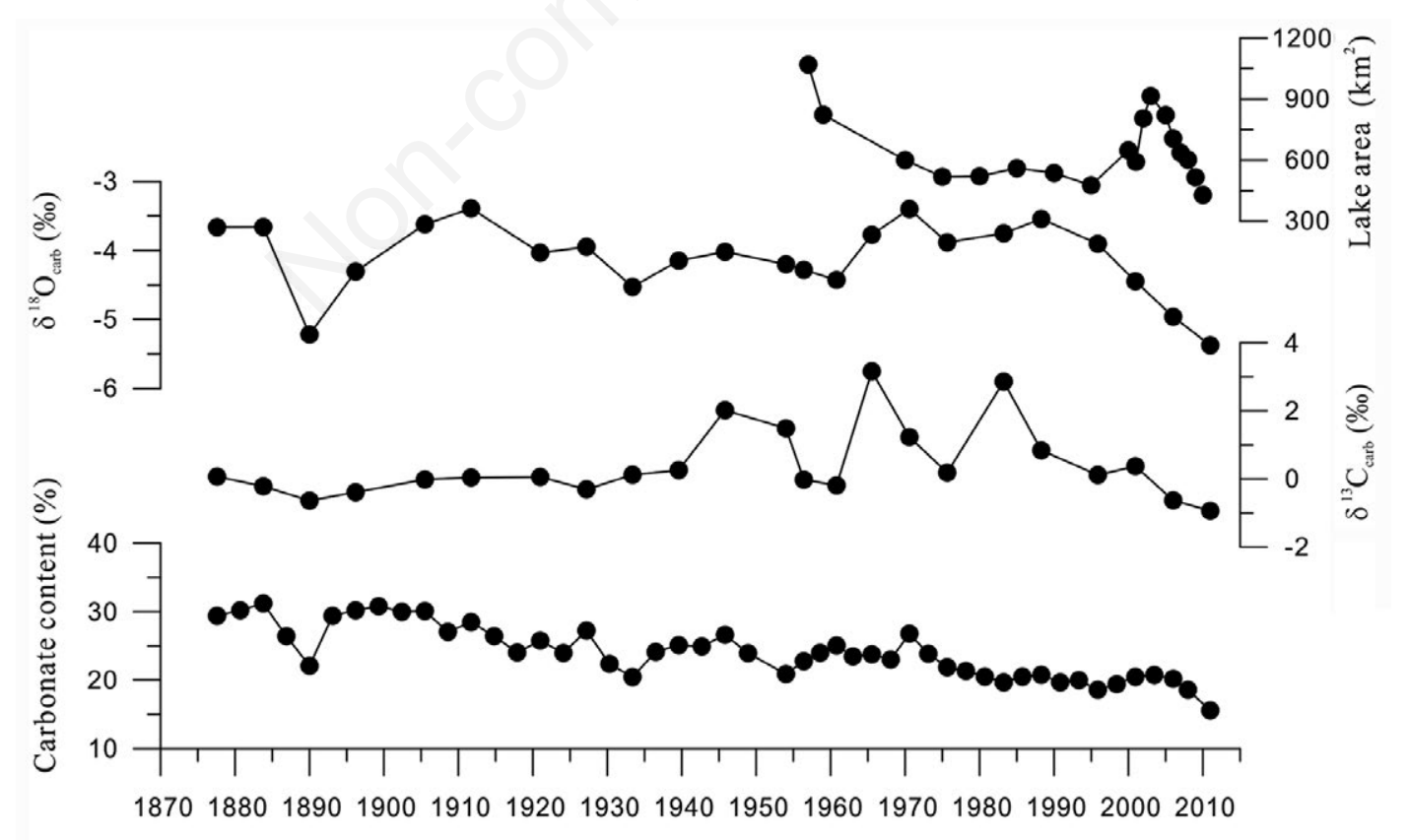

Time (years AD)

Fig. 7. Variations in carbonate content, $\delta^{13} \mathrm{C}_{\text {carb }}$, and $\delta^{18} \mathrm{O}_{\text {carb }}$ in the Ebinur Lake sediment core compared with the changes in lake area, which is shown using an inverted scale (Ma et al., 2007). 
ity. These values show a clear shift in the late 1930s. From this time onwards, TOC and TN increased, which suggests the prevalence of climatic conditions that were more suitable for the growth of plants. The $\mathrm{C} / \mathrm{N}$ ratios and organic carbon isotopes reveal that the proportion of endogenous organic matter tended to increase during this time.

Clear variations in heavy metal accumulation began in the mid 1950s. However, from the early 2000s, the EFs of all heavy metals were relatively reduced. This is likely associated with the establishment of wetland nature reserves, which are effective at removing heavy metals from runoff water. Although the enrichment factors for heavy metals showed considerable variation, a risk assessment of the toxicity of these heavy metals showed that the potential ecological risk was slight.

The stable isotopes of bulk carbonate tend to vary along with the lake level, which is sensitive to the association between climatic and anthropogenic influences.

The environmental proxies measured here each responded to climate change and human activities to different degrees. Therefore, paleo-environmental reconstructions should aim to take full account of the role of human activities on environmental indicators in lakes, especially in studies covering short time scales.

\section{ACKNOWLEDGEMENTS}

We thank anonymous reviewers for their valuable comments and constructive suggestions. This study was supported by the National Natural Science Foundation of China (41501221; 41471173; 41671200), and the West Light Foundation of The Chinese Academy of Sciences (2015-XBQN-B-18). The authors also gratefully acknowledge the supports of the High-level Talents Introduction Project in Xinjiang Uygur Autonomous Region (2015) and Youth Innovation Promotion Association CAS.

\section{REFERENCES}

Adger W, Agrawala S, Mirza M, Conde C, O’Brien K, Pulhin J, Pulwarty R, Smit B, Takahashi K, 2007. Working group II: impacts, adaptation and vulnerability. Fourth assessment report of the intergovernmental panel on climate change. Cambridge University Press, Cambridge.

Aizen VB, Aizen EM, Melack JM, Dozier J, 1997. Climatic and hydrologic changes in the Tien Shan, central Asia. J. Clim. 10:1393-1404.

Appleby PG, 2002. Chronostratigraphic techniques in recent sediments, p. 171-203. In: W.M. Last and J.P. Smol (eds.), Tracking environmental change using lake sediments. Springer.

Austin P, Mackay A, Palagushkina O, Leng M, 2007. A highresolution diatom-inferred palaeoconductivity and lake level record of the Aral Sea for the last 1600 yr. Quat. Res. 67:383-393.

Binford MW, 1990. Calculation and uncertainty analysis of
$210 \mathrm{~Pb}$ dates for PIRLA project lake sediment cores. J. Paleolimn. 3:253-267.

Bing H, Wu Y, Zhou J, Li R, Wang J, 2016. Historical trends of anthropogenic metals in Eastern Tibetan Plateau as reconstructed from alpine lake sediments over the last century. Chemosphere 148:211-219.

Birks HJB, Jones VJ, Rose NL, 2004. Recent environmental change and atmospheric contamination on Svalbard as recorded in lake sediments-synthesis and general conclusions. J. Paleolimn. 31:531-546.

Bourennane H, Douay F, Sterckeman T, Villanneau E, Ciesielski H, King D, Baize D, 2010. Mapping of anthropogenic trace elements inputs in agricultural topsoil from Northern France using enrichment factors. Geoderma 157:165-174.

Chen F, Chen J, Holmes J, Boomer I, Austin P, Gates JB, Wang N, Brooks SJ, Zhang J, 2010. Moisture changes over the last millennium in arid central Asia: a review, synthesis and comparison with monsoon region. Quat. Sci. Rev. 29:10551068.

Chen F, Yu Z, Yang M, Ito E, Wang S, Madsen DB, Huang X, Zhao Y, Sato T, Birks HJB, 2008. Holocene moisture evolution in arid central Asia and its out-of-phase relationship with Asian monsoon history. Quat. Sci. Rev. 27:351-364.

Chiba T, Endo K, Sugai T, Haraguchi T, Kondo R, Kubota J, 2016. Reconstruction of Lake Balkhash levels and precipitation/evaporation changes during the last 2000 years from fossil diatom assemblages. Quatern. Int. 397:330-341.

Dearing JA, Jones RT, Shen J, Yang X, Boyle JF, Foster GC, Crook DS, Elvin MJD, 2008. Using multiple archives to understand past and present climate-human-environment interactions: the lake Erhai catchment, Yunnan Province, China. J. Paleolimnol. 40:3-31.

Donat MG, Lowry AL, Alexander LV, Ogorman PA, Maher N, 2016. More extreme precipitation in the world[rsquor]s dry and wet regions. Nature Clim. Change 6:508-513.

Fritz P, Anderson T, Lewis C, 1975. Late-Quaternary climatic trends and history of Lake Erie from stable isotope studies. Science 190:267-269.

Gu Y, Wang Z, Lu S, Jiang S, Mu D, Shu Y, 2012. Multivariate statistical and GIS-based approach to identify source of anthropogenic impacts on metallic elements in sediments from the mid Guangdong coasts, China. Environ. Pollut. 163:248-255.

Hakanson L, 1980. An ecological risk index for aquatic pollution control. A sedimentological approach. Water Res. 14:975-1001.

Hammer Ø, 2013. PAST Paleontological Statistics ver. 3.0: Reference Manual. University of Oslo.

Hatfield JL, Prueger JH, 2015. Temperature extremes: Effect on plant growth and development. Weather Clim. Extrem. 10 Part A:4-10.

Hong B, Gasse F, Uchida M, Hong Y, Leng X, Shibata Y, An N, Zhu Y, Wang Y, 2014. Increasing summer rainfall in arid eastern-Central Asia over the past 8500 years. Sci. Rep. 4:5279.

Huang W, Chen F, Feng S, Chen J, Zhang X, 2013. Interannual precipitation variations in the mid-latitude Asia and their association with large-scale atmospheric circulation. Chinese Sci. Bull. 58:3962-3968.

Klaminder J, Appleby P, Crook P, Renberg I, 2012. Post-depo- 
sition diffusion of $137 \mathrm{Cs}$ in lake sediment: Implications for radiocaesium dating. Sedimentology 59:2259-2267.

Legendre P, 1987. Constrained clustering, p. 289-307. In: P. Legendre and L. Legendre (eds.), Developments in numerical ecology. NATO ASI Series (Series G: Ecological Sciences). 14. Springer, Berlin.

Lewis C, Anderson T, 1992. Stable isotope (O and C) and pollen trends in eastern Lake Erie, evidence for a locally-induced climatic reversal of Younger Dryas age in the Great Lakes basin. Clim. Dyn. 6:241-250.

Lioubimtseva E, Cole R, Adams J, Kapustin G, 2005. Impacts of climate and land-cover changes in arid lands of Central Asia. J. Arid. Environ. 62:285-308.

Lioubimtseva E, Henebry GM, 2009. Climate and environmental change in arid Central Asia: Impacts, vulnerability, and adaptations. J. Arid. Environ. 73:963-977.

Liu G, Liu Z, Li Y, Chen F, Gu B, Smoak JM, 2009. Effects of fish introduction and eutrophication on the cladoceran community in Lake Fuxian, a deep oligotrophic lake in southwest China. J. Paleolimnol. 42:427-435.

Liu W, Wu J, Ma L, Zeng H, 2014. A 200-year sediment record of environmental change from Lake Sayram, Tianshan Mountains in China. GFF 136:548-555.

Loeppert RH, Suarez DL, 1996. Carbonate and gypsum. USDAARS / UNL Faculty.

Loska K, Cebula J, Pelczar J, Wiechuła D, Kwapuliński J, 1997. Use of enrichment, and contamination factors together with geoaccumulation indexes to evaluate the content of $\mathrm{Cd}, \mathrm{Cu}$, and $\mathrm{Ni}$ in the Rybnik water reservoir in Poland. Water Air Soil Poll. 93:347-365.

Ma L, Wu J, Abuduwaili J, 2013. Climate and environmental changes over the past 150 years inferred from the sediments of Chaiwopu Lake, central Tianshan Mountains, northwest China. Int. J Earth Sci. 102:959-967.

Ma L, Wu J, Abuduwaili J, Liu W, 2016. Geochemical responses to anthropogenic and natural influences in Ebinur Lake sediments of arid Northwest China. PloS One 11:e0155819.

Ma L, Wu J, Liu W, Abuduwaili J, 2014. Distinguishing between anthropogenic and climatic impacts on lake size: a modeling approach using data from Ebinur Lake in arid northwest China. J. Limnol. 73:350-357.

Ma L, Wu J, Yu H, Zeng H, Abuduwaili J, 2011. The medieval warm period and the little Ice age from a sediment record of Lake Ebinur, Northwest China. Boreas 40:518-524.

Ma M, Wang X, Veroustraete F, Dong L, 2007. Change in area of Ebinur Lake during the 1998-2005 period. Int. J. Remote Sens. 28:5523-5533.

Meyers PA, 2003. Applications of organic geochemistry to paleolimnological reconstructions: a summary of examples from the Laurentian Great Lakes. Org. Geochem. 34:261-289.

Meyers PA, Lallier-Vergès E, 1999. Lacustrine sedimentary organic matter records of Late Quaternary paleoclimates. J. Paleolimnol. 21:345-372.

Meyers PA, Teranes JL, 2002. Sediment organic matter, p. 239269. In: W.M. Last and J.P. Smol (eds.), Tracking environmental change using lake sediments. Springer.

Muller J, Wüst RAJ, Weiss D, Hu Y, 2006. Geochemical and stratigraphic evidence of environmental change at Lynch's Crater, Queensland, Australia. Glob. Planet. Change 53: 269-277.
Peng D, Qiu L, Fang J, Zhang Z, 2016. Quantification of climate changes and human activities that impact runoff in the Taihu Lake basin, China. Math. Probl. Eng. 2016: 2194196.

Pennington W, Tutin T, Cambray R, Fisher E, 1973. Observations on lake sediments using fallout $137 \mathrm{Cs}$ as a tracer. Nature 242:324-326.

Price N, Brand T, Pates JM, Mowbray S, Theocharis A, Civitarese G, Miserocchi S, Heussner S, Lindsay F, 1999. Horizontal distributions of biogenic and lithogenic elements of suspended particulate matter in the Mediterranean Sea. Prog. Oceanogr. 44:191-218.

Qiang M, Liu Y, Jin Y, Song L, Huang X, Chen F, 2014. Holocene record of eolian activity from Genggahai Lake, northeastern Qinghai - Tibetan Plateau, China. Geophys. Res. Lett. 41:589-595.

Rauch S, Hemond HF, Peucker-Ehrenbrink B, 2004. Source characterisation of atmospheric platinum group element deposition into an ombrotrophic peat bog. J. Environ. Monit. 6:335-343.

Reimann C, De Caritat P, 2005. Distinguishing between natural and anthropogenic sources for elements in the environment: regional geochemical surveys versus enrichment factors. Sci. Total Environ. 337:91-107.

Sabit M, Yusup R, 2007. [Analysis on the spatial and teporial changes of population and its Influencing factors in Xinjiang in the last 50 years].[In Chinese with English abstract]. Human Geogr. 22:114-119.

Stocker TF, Qin D, Plattner G-K, Tignor M, Allen SK, Boschung J, Nauels A, Xia Y, Bex V, Midgley PM, 2014. Climate change 2013: The physical science basis. Cambridge University Press, Cambridge.

Sun H, Ma J, Wang S, Zhang X, 2007. [The study of stable carbon isotope composition in desert plants of Junggar Basin].[In Chinese with English abstract]. J. Desert Res. 27:972-976.

Talbot M, 1990. A review of the palaeohydrological interpretation of carbon and oxygen isotopic ratios in primary lacustrine carbonates. Chem. Geol. 80:261-279.

Tang Q, Zhang C, 2013. Data Processing System (DPS) software with experimental design, statistical analysis and data mining developed for use in entomological research. Insect Sci. 20:254-260.

Thevenon F, De Alencastro LF, Loizeau J-L, Adatte T, Grandjean D, Wildi W, Poté J, 2013. A high-resolution historical sediment record of nutrients, trace elements and organochlorines (DDT and PCB) deposition in a drinking water reservoir (Lake Brêt, Switzerland) points at local and regional pollutant sources. Chemosphere 90:2444-2452.

Walkley A, Black IA, 1934. An examination of the Degtjareff method for determining soil organic matter, and a proposed modification of the chromic acid titration method. Soil Sci.37:29-38.

Wang S, Dou H, 1998. [Lakes in China].[Book in Chinese]. Science, Beijing.

Wu J, Yu Z, Wang N, 2009. Possible solar forcing of 400-year wet-dry climate cycles in northwestern China. Clim. Change 96:473-482.

Xu H, Ai L, Tan L, An Z, 2006. Stable isotopes in bulk carbonates and organic matter in recent sediments of Lake Qinghai and their climatic implications. Chem. Geol. 235:262-275. 
Yao J, Liu Z, Yang Q, Meng X, Li C, 2014. Responses of runoff to climate change and human activities in the Ebinur Lake Catchment, western China. Water Resour. 41:738-747.

Ye X, Zhang Q, Liu J, Li X, Xu C-Y, 2013. Distinguishing the relative impacts of climate change and human activities on variation of streamflow in the Poyang Lake catchment, China. J. Hydrol. 494:83-95.

Yu F, Price KP, Ellis J, Shi P, 2003. Response of seasonal vege- tation development to climatic variations in eastern central Asia. Remote Sens. Environ. 87:42-54.

Zhang Y, Wu F, Zhang R, Liao H, Ling H, 2009. [Sediment records of heavy metal pollution in Bosten Lake, Xinjiang].[In Chinese with English abstract]. Earth Environ. 37:50-55.

Zhang Z, Cui B, Fan X, 2012. Removal mechanisms of heavy metal pollution from urban runoff in wetlands. Front. Earth Sci. 6:433-444. 